\title{
ARE YOU “(WO)MAN” ENOUGH TO GET MARRIED?
}

\author{
Tiurma M. P. Allagan*
}

* Faculty of Law University of Groningen, the Netherlands

\section{Article Info}

Received : 11 July 2016 | Received in revised form : 11 November 2016 | Accepted : 25 November 2016 Corresponding author's e-mail : pitta_allagan@yahoo.com

\begin{abstract}
The Indonesian Marriage Law states that marriage is a physical and spiritual relationship between a man and a woman as husband and wife in order to create an eternal happy family based on the Almighty God. This definition reflects that marriages in Indonesia must be between heterosexual couples. However, a question appears as to whether a man or a woman mentioned thereof includes a man and a woman who were hermaphrodite, intersex, or nowadays known as a person with Disorder of Sexual Development (DSD)? The case of AH whereby his marriage was cancelled by the Supreme Court in 2014 for since he was not considered as a man, confirms that this question is important to value the capacity of a person to marry. This writing will apply normative research as well as literature research methods upon the positive rules and regulations. The decisions of district courts upon the revision or change of gender and its legal basis will be analyzed and be the topic of discussion. The comparison will then be applied to compare the marriage requirements between Indonesian Law, Singaporean Law and Hong Kongese Law. The results of analysis and discussion will be the closure of the writing, as conclusions and advice, if any.
\end{abstract}

Keywords: Intersexual, Indonesian Marriage Law, Person with Disorder of Sexual Development (DSD), Marriage Cancelation

\begin{abstract}
Abstrak
Perkawinandalam UU Perkawinan di Indonesia dinyatakan sebagai ikatan lahir bathin antara seorang pria dan seorang wanita sebagai suami istri dengan tujuan membentuk keluarga (rumah tangga) yang bahagia dan kekal berdasarkan Ketuhanan Yang Maha Esa. Definisi ini merefleksikan bahwa perkawinan di Indonesia merupakan perkawinan pasangan yang heteroseksual. Namun pertanyaan muncul apakah lelaki atau perempuan yang disebutkan mencakup definisi lelaki atau perempuan yang sebelumnya merupakan pasien berkelamin ganda, interseks atau saat ini dikenal sebagai manusia "Disorder of Sexual Development (DSD)"? Kasus AH yang dibatalkan perkawinannya oleh Mahkamah Agung pada tahun 2014 yang tidak menganggap dia adalah seorang lelaki, semakin memperjelas bahwa pertanyaan ini menjadi penting untuk menilai kapasitas seseorang untuk melaksanakan perkawinan. Penulisan ini menggunakan metode penelitiannormatif dimana penelitian kepustakaan atas hokum dan peraturan yang berlaku dilaksanakan. Penetapan pengadilan atas revisi atau perubahan jenis kelamin dan dasar hokum putusannya akan dianalisis dan menjadi bahan diskusi. Metode perbandingan juga dipergunakan untuk membandingkan persyaratan perkawinan antara hukum Indonesia dengan hokum Singapura dan Hong Kong. Hasil analisis dan diskusi dari topic tersebut di atas akan dipergunakan untuk menutup tulisan ini sebagai kesimpulan dan saran (jika ada).
\end{abstract}

Kata Kunci: Interseks, Hukum Perkawinan di Indonesia, Manusia Disorder of Sexual Development (DSD), Pembatalan Perkawinan 


\section{INTRODUCTION}

Sexual reassignment surgery has become an issue in Indonesia since 1973. The District Court of South-West Jakarta, at that time, granted the request of the applicant that made him/her legally a woman as of the issuance date of district court decision. ${ }^{1}$ Based on such decision, the data of the applicant in the Civil Registry Office was yet amended. At that time, the case was considered as a progressive decision. ${ }^{2}$ The judge clearly mentioned in his consideration that the sexual reassignment issue from a legal perspective has an enormous impact in the society. The judge mentioned that there were no law or regulations which stipulated this particular issue. Therefore, the judge referred to the general principles of rules of law. In addition, the judge also valued the testimony and opinion of the religion of the claimant.

Interestingly, this decision was issued a year before Law No.1 of 1974 regarding Marriage was promulgated (hereinafter referred to as the "MA 1974") 3 . Chronologically, it should be considered that the MA 1974 includes men and women who have undergone reassignment surgery and had the district court decision upon it. But there was no confirmation or clarification to this issue in its official elucidation. The case of $\mathrm{AH}$ in 2014 indicates the ambiguity of this question or requirement. Therefore, it is reasonable to elaborate the issue of people with Disorder of Sexual Development ("DSD") and their capacity to marry; issues of homosexual, lesbian, bisexual and transgender are beyond of this writing.

This writing would like to answer the question of what are the definitions of "a man" and "a woman" as stated in the MA 1974? Does it include people with DSD who have undergone reconstruction surgeries, to be identified as a "man" or a "woman" according to the MA 1974? Also, the questions of who can determine the sexual identity of a person with DSD and whether there is any possibility to change a person's sexual identity according to the Indonesian Law? Lastly, how do reconstruction surgeries impact the capacity to marry according to the Indonesian Law?

The writing will be based on the normative approach to the prevailing law and regulations in Indonesia, as relevant. The decision of district courts, in particular its legal considerations in relevant cases will be compared and analyzed.

In addition to the above, marriage requirements to the prevailing regulations of Singapore and Hong Kong, in particular the sexual identity, will also be compared. Both countries have been chosen because many Indonesian couples tend to solemnize their marriage there, other than any other countries.

By performing the above approach and comparison, this writing will be exploring the definition of "man" and "woman" in the requirement of marriage in Indonesia as stipulated in the MA 1974. It is to affirm as to whether the term "man" and "woman" also includes a man or a woman who was a person with DSD (previously known as

1 District Court of South and West Jakarta, “Decree No. 546/Pdt.P/1973". The decision granted the change of from male-to-female transgender and the name of the applicant also changed from IwanRubiyanto to be Vivian Rubiyanti Iskandar.

See Ahmad Ubbe, "Putusan Hakim sebagai 'Rekayasa Sosial' dalam Pembinaan Hukum Nasional [Court Decision as 'Social Engineering' in National Law Development]," Majalah Hukum Nasional, no. 1 (2002): 71-89. The same idea also written by Joko Sri Widodo, "Putusan Hakim sebagai 'Rekayasa Sosial' dalam Pembinaan Hukum Nasional [Court Decision as 'Social Engineering' in National Law Development]," Majalah Hukum Nasional, no. 1 (2002): 62-73.

${ }^{3}$ Indonesia, Undang-Undang tentang Perkawinan (Law regarding Marriage), Undang-Undang Nomor 1 tahun 1974, LN No. 1 tahun 1974, TLN No. 3019 (Law No. 1 of 1974, SG No. 1 of 1974). (hereinafter referred as "MA 1974") 
hermaphrodite or intersex) who has undergone surgery. Comparison to Singapore and Hong Kong is about to sharpen the definition and interpretation of "man" and "woman" which could or might be possible to be adopted.

This writing will use particular terminologies which will be defines below. A person with DSD is a person who has ambiguous genital organ(s) or sex ambiguity. The person has anatomical and physiological symptoms which causes doubt as to whether s/he is a man or a woman, previously known as the intersexual person. The terminology refers to the traditional sexes (man and woman) yet this DSD's situation is in between of the two sexual identities. The genital organs, either external and/ or internal, are between those of a man's and a woman's. Reassignment surgery is a surgical procedure to replace the original primary genital organ to the opposite sexual identity. The reassignment surgery procedure involves the removal of the primary sexual organ and implants the external sexual organ, which can be male-to-female or vice versa. ${ }^{4}$

Reconstruction surgery is under the scope of plastic surgery and it is a medical action that is undertaken for recovery or to increase the physical health condition of patients which focuses on the appearance and its function. ${ }^{5}$

\section{THE REQUIREMENTS OF HETEROSEXUAL COUPLE}

The general requirements to marry in Indonesia, Singapore and Hong Kong cover the same items. Those countries stand by the monogamy principle, consent from parties tied to the marriage, heterosexual couples (a man and a woman), minimum age and approval needed from parents. There are also prohibitions which forbid couples to marry should they have significantly close blood relations or adoption.

The general requirements of marriage are slightly similar one to each other, save for the monogamy principle and heterosexual couples. The absolute monogamy principle is adopted in Singapore and Hong Kong, while Indonesia adopted the limited monogamy principle, in which polygamous marriage could only occur if the couple obtains a prior decision by the district court to do so upon specific circumstances. ${ }^{6}$

This sub-chapter will emphasize one of the marriage requirements, in particular heterosexual couples.

\section{A. Singapore}

The marriage law in Singapore is embodied in an act known as the Women's Charter (1961), ${ }^{7}$ which requires that two people cannot marry each other unless they are of different sexes. Therefore, only heterosexual couples can marry. Section 12 (1)

${ }^{4}$ Janell Carroll, Sexuality Now: Embracing Diversity, 2nd ed. (Belmont: Thompson Wadsworth, 2007), p.87.

5 Indonesia, Undang-undang tentang Kesehatan (Law regarding Health), UU No.36 Tahun 2009, LN No.144 Tahun 2009, LN No.144 Tahun2009 (Law No.36 of 2009, SG No.144 Year 2009), the Official Elucidation of Art. 37. (hereinafter referred as "Indonesian Health Law")

6 MA 1974, Art.3-5. See Indonesia, Peraturan Pemerintah tentang Pelaksanaan UU No.1 tahun 1974 tentang Perkawinan (Government Regulation regarding Implementation Regulation of Law No.1 of 1974 regarding Marriage), Peraturan Pemerintah No.9 Tahun 1975, LN No.12 of 1975 (Government Regulation No.9 of 1975,SG No.12 of 1975), Art.40, 41.

7 The Women's Charter of Singapore, the Ordinance No.18 of 1961, Chapter 353 commenced on 15 September 1961, as amended to date. 
of the Women's Charter mentions that a marriage between two people, who at the date of the marriage are not respectively male and female, shall be void. ${ }^{8}$

The sex identity of the person for this purpose must be stated at the time of the marriage in which their identity card issued based on the National Registration Act, and a person who has undergone a sex reassignment surgery shall be identified as the sex of which the person has been re-assigned to. The section 12 (3) of Women's Charter was added in 1996, giving legal recognition to sex re-assignment surgery for the purposes of fulfilling the statutory prescription of parties being of different sexes. ${ }^{9}$

\section{B. Hong Kong}

Section 4 of the Hong Kong Marriage Ordinance $(1971)^{10}$ (hereinafter briefly referred to as HMO) states that two people cannot marry each other unless they are of different sexes, therefore only heterosexual couples can get married. The requirement of different sexes or marrying the opposite sex person also includes any person who are transsexual by having the re-assignment surgery. Same-sex marriage is forbidden and will not be recognized in Hong Kong, as according to HMO, marriage is a voluntarily union for life of one man and one woman to the exclusion of all others. ${ }^{11}$ This stipulation was amended after the decision of the Court of Final Appeal in the case of W vs. the Registrar of Marriage. ${ }^{12}$ Prior to that decision, the law of Hong Kong did not recognize the right of a post-operative transsexual to marry.

The case of W vs. the Registrar of Marriage was requested by a person who was a female transsexual, having gone through the reassignment surgery. She was refused by the Registrar of Marriage (hereinafter briefly referred as ROM) to marry a man based on the ground that she was biologically a man; therefore, she could not marry a man. She challenged the decision of the ROM by asking for a judicial review upon the interpretation of "female" under section 21 and 40 of the HMO, as well as challenging the constitutionality of the HMO by claiming an infringement to her right to marry as provided in Section 37 of the Basic Law of Hong Kong and Article 19 (2) of the Hong Kong Bill of Rights. The Court of First Instance and the Court of Appeal gave order against W, yet the Court of First Instance suggested the government to conduct a public consultation on gender identity, sexual orientation, and specific problems and difficulties faced by transgender people, including the right to marry. However, the

\footnotetext{
${ }^{8}$ Section 12 the Women's Charter. "(1) A marriage solemnized in Singapore or elsewhere between persons who, at the date of the marriage, are not respectively male and female shall be void. (2) It is hereby declared that, subject to sections 5, 9, 10, 11 and 12, a marriage solemnized in Singapore or elsewhere between a person who has undergone a sex reassignment procedure and any person of the opposite sex is and shall be deemed always to have been a valid marriage. (3) For the purpose of this section (a) the sex of any party to a marriage as stated at the time of the marriage in her identity card issued under the National Registration Act (Cap 201) shall be prima facie evidence of the sex of the party; and (b) a person who has undergone a sex reassignment procedure shall be identified as being of the sex to which the person has been assigned. (4) Nothing in subsection (2) shall be validate any such marriage which had been declares by the High Court before 1st May 1997 to be null and void on the ground that the parties were of the same sex."

${ }^{9}$ Leong WaiKum, Elements of Family Law in Singapore, 2nd Ed. (Singapore: LexisNexis, 2012), p.36.

10 The Hong Kong Marriage Ordinance, Cap.181 of 1950, as amended to date.

11 Ibid., Sec. 40 of HMO.

12 Hong Kong Court of Final Appeal in the case of W v. The Registrar of Marriages (FACV 4/2012). See http://legalref.judiciary.gov.hk/doc/judg/html/vetted/other/en/2012/FACV000004 2012 files/ FACV000004 2012ES.htm also the popular website regarding marriage in Hong Kong http://familyclic. hk/en/topics/Matrimonial-matters/Marriage-and-co-habitant-issues/Transsexual-marriage/, accessed on 4 June 2016.
} 
Court of Final Appeal decided the opposite, whereby it declared that a "woman" and "female" in the HMO also included post-operation male-to-female transsexual people who have been certified by an appropriate medical authority as having changed the gender by reassignment surgery. Accordingly, the Court viewed that under the law, the applicant is entitled to be included as a woman and therefore has the right to marry a man.

\section{Indonesia}

From the definition stipulated in Article 1 of the MA 1974, it is stated that the couples must consist of a man and a woman, also known as heterosexual couples. Yet, this definition does not mention whether the men or women must be men or women since birth, or if it includes men or women who have undergone reassignment surgery or reconstruction surgery.

The MA 1974 is silent about same-sex marriages, yet the Indonesian society is still holding tightly religious and traditional values; therefore, it could be concluded that same-sex marriage is inacceptable in Indonesia. Some scholars mention that it is clearly forbidden based on religions values. In addition, it is not in line with the nature and purposes of marriage due to the inability to procreate in same-sex marriages. ${ }^{13}$

\section{MALE/MAN OR FEMALE/WOMAN OR PERSON WITH DSD}

In relation with heterosexual couple being a requirement of marriage, the Women's Charter and HMO are including the phrase "The women or men who have undergone reassignment surgeries." It is worth noting that the background of the stipulation was about the sexual identity of the persons, either he or she has undergone reassignment surgery or reconstruction surgery.

Since the first case in 1973, there were some district court decisions in Indonesia which acknowledge the sexual identity of a person after he or she has undergone reassignment surgery or reconstruction surgery, either male-to-female or vice versa. ${ }^{14}$

There was a well-known Indonesian athlete, previously known as Sukarnah. Sukarnah, as a woman, was the awardee of the bronze medal for javelin of the SEA

${ }^{13}$ The stipulation of the same-sex couples in Indonesia in the future is un-known. Up to now, the Indonesian society seems reluctant to accept same-sex marriage, though in fact there are some couples who are silently live together. It needs a lot of data and long discussion to this issue. The author is confident to state that Indonesia is still difficult to accept the same-sex marriage as modern ways of living.

${ }^{14}$ The 13 decisions collected by the author are: (1) South-West Jakarta District Court, Decision No.546/ Pdt.P/1973; (2) Semarang District Court, Decision No.595/Pdt.P/1990/PN.Semarang; (3) Bantul District Court, Decision No.22/Pdt.P/2003/PN.Btl.; (4) Batang District Court, Decision No.19/Pdt.P/2009/PN.Btg.; (5) Ungaran District Court, Decision of No.20/Pdt.P/2009/PN.Ung.; (6) Jayapura District Court, Decision No.12/Pdt.P/2010/PN.Jpr.; (7) Semarang District Court, decision No.3077/Pdt.P/2011/PN Semarang; (8) Boyolali District Court, Decision No.07/Pdt.P/2011/PN.Bi; (9) Cibinong District Court, Decision No.685/ Pdt.P/2012/PN.Cbn.; (10) Kendal District Court, Decision No.3332/Pdt.P/2012/PN.Kdl.; (11) Yogyakarta District Court, Decision No.517/Pdt.P/2012/PN.YK; (12) Ungaran District Court, Decision No.518/ Pdt.P/2013/PN.Ung; (13) Boyolali District Court, Decision No.54/Pdt.P/2015/PN.Byl.; (14) Kebumen District Court, Decision No.17/Pdt.P/2015/PN.Kbm. Besides those same cases, there were cases which only known or identified from the news by their names among others Sri Wahyuni based on the Decision of Makassar District Court, Sukarnah alias IwanSetiawan and Dorce Gamalama, a well-known tv personality in Indonesia. 
Games in Tokyo, 1958. ${ }^{15}$ Sukarnah was divorced from her husband with no child. She is now known as Iwan Setiawan, a man with a wife and child.

Sukarnah transitioned to man. Obtaining the Statement Letter from the RSPAD Gatot Subroto, which stated that Iwan Setiawan is a man, including three hearings before the Religious Court became the process he must take for his transformation. The hearings were part of the process of the examination of his sexual identity before his marriage could be validated by the Religious Affairs Office (Kantor Urusan Agama). The fact that he had failed gender examination to participate in the Olympics in Melbourne in 1956 and the SEA Games in 1962 twice provide indications that, previously, there was doubt regarding the sexual identity of Sukarnah or Iwan. This case indicated that the condition of Sukarnah or Iwan was scrutinized, but no court decision was involved.

There were also several cases of marriage cancellations, one of them was the case in the District Court of Jatiasih, Bekasi, West Java in $2010 .{ }^{16}$ The couple was identified as having the same sex. Both of them were considered women although one of them appeared and dressed as a man. The prosecutor argued that the sexual identity was given dishonestly by the couple to the Civil Registration Office or Religious Affairs Office (Kantor Urusan Agama). In this case, no medical examination was involved.

The latest case was case of AH (husband) vs JD (wife) in 2014. AH and JD met in 2008 in a women's golf country club where AH was a member. In the same year, they got married in Los Angeles as stated in the Nevada State Marriage Certificate and registered in the Indonesian Embassy in United States. They married without an approval from the parents' bride. For this, the mother-in-law of AH objected their marriage.

The case was brought before the Indonesian court. First, AH was accused of committing identity fraud, but AH was released from this criminal case in 2011. ${ }^{17}$ During the criminal case, in $2010 \mathrm{AH}$ received a decision from the Jayapura District Court that allowed him to have correction in his legal documents from a woman to be a man. ${ }^{18}$ JD was faithful to her husband during the hearing of the criminal case. But when it was over, JD claimed against AH for tort (onrechmatigedaad) for using her inability to lead her in a marriage and for using her money for his own purpose. She requested the court to cancel their marriage as their marriage was a same-sex marriage which is forbidden in Indonesia. JD was asked for a divorce as a reply.

The judge in South Jakarta District Court stated that administratively AH is indeed a man as stated in the decision of Jayapura District Court. For this decision, the judge had two expert witnesses. First, the forensic expert who stated that $\mathrm{AH}$ is a man with

${ }^{15}$ PT. Korindo Tour, “Sukarnah, Wanita Peraih Medali ASEAN Games Yang berubah menjadi Pria”, http:// www.korindo99.com/client ini/asp/customer/sekilas/view.asp?nseq=1390, accessed 28 June 2016. Some blogs also repeat the same story about Sukarnah who then became IwanSetiawan.

16 Supreme Court of Republic of Indonesia, "Decision No.1103 K/Pdt/2014," p. 6. This decision refers to the marriage cancellation case of RS (also known as FAO) with MU registered in Marriage Certificate No.966/155/IX/2010 which then cancelled for it is considered as a same-sex marriage. The marriage was cancelled by the District Court of Jatiasih Bekasi, West Java and then quoted in the Supreme Court Decision No.1103 K/Pdt/2014.

17 South Jakarta District Court of Republic of Indonesia, "Decision No.583/Pid.B/2010/PN.Jkt.Sel." dated 23 November 2010 jo. Supreme Court of Republic of Indonesia, “Decision No.704 K/Pid/2011,” dated 31 May 2011.

18 Jayapura District Court of Republic of Indonesia, Decision No.12/Pdt.P/2010/PN.JPR dated 29 March 2010. 
klinefelter syndrome. ${ }^{19}$ Second, the geneticist who stated that, genetically, AH has woman chromosome. However, the judge disregarded the first expert's testimony that $\mathrm{AH}$ is a man with klinefelter syndrome. The judge emphasized that $\mathrm{AH}$ has woman chromosome, and further concluded that even if $\mathrm{AH}$ is a man, he is not a real man. The judge concluded that $\mathrm{AH}$ is a woman. He decided the cancellation of marriage, instead of divorce.

Notwithstanding the authority of the judge to adjudicate the case and decided $\mathrm{AH}$ was a woman, it is worth reconsidering what is a man and woman according to the medical perspective and the condition of $\mathrm{AH}$.

Sexual identity became the central issue in the above case. It shows that determining a man or a woman is not as easy as we thought. The case of AH and JD shows that the MA 1974 needs to clarify the definition of man and woman. Should it adopt the definitions as mentioned in the Women's Charter or HMO must be based on Indonesian values.

\section{A. Person with DSDs (also known as Ambiguous Genitalia)}

The sexual identity of babies are usually easy to determine. Only seconds after birth, a doctor or someone who helps the birth delivery could determine whether the baby is a boy or a girl. Moreover, nowadays with high medical technology, namely ultrasonography (USG), a fetus in the womb could have their sexual identity identified. $^{20}$

However, some babies cannot be identified easily. Sometimes there are babies who have unclear external genital organs or maybe look alike that they have both of a penis and a vagina. This condition can happen once out of 4.500 births, called as "ambiguous genitalia" or in Indonesia called as "berkelamin ganda", "jenis kelamin meragukan" or "membingungkan". ${ }^{21}$ The ambiguous genital or sex ambiguity is a disarray condition suffered by a patient who has symptoms, anatomical and physiological symptoms which causes doubt as to whether the patient is a man or a woman. This kind of disorder is previously known as intersexual, where the terminology refers to traditional sexual identities that are man and woman. Nowadays, endocrinologists call this situation as the "Disorders of Sexual Developments (DSDs)". ${ }^{22}$

For civil registration purposes or other purposes, the parents or doctor must immediately determine the sexual identity of the baby. This is natural, however this decision for babies with DSD could be is error-prone. These errors appear years after the babies are grown up. Babies who had been determined as "a girl" shows masculinity, no menstruation and flat chest in her teenager or puberty period, or vice versa. In addition, the data in civil registration office will determine and influence the role and education of the respective baby. In early years, this error could be no problem; however, when the baby grows up it could become a psychosocial problem.

${ }^{19}$ It was mentioned also that AH took bilateral mastectomy. He is not a woman as he has penis though it is not normal, also testis (the primary genital of a man) and no vagina.

${ }^{20}$ H. Daniel Polk, Abnormalities of Sexual Differentiation, Harrison's Endocrinology (Mcgraw-Hill: New York, 2006), pp.161-172.

${ }^{21}$ Bambang Widhiatmoko and Eddy Suyanto, "Legalitas Jenis Kelamin pada Penderita Ambiguous Genetalia di Indonesia [Legal Aspect of Sexual Identity of the Ambiguous Genitals Patients in Indonesia]" Jurnal Kedokteran Forensik Indonesia 15, no. 1 (Jan-March 2013), pp.15-18.

22 Ibid. 
The determination of sex in the embryo has three phases: genetically (chromosome), a form of gonadal, and a form of phenotype. Any disturbance or disorder to any development canhappen from the beginning, since the person was in the womb. ${ }^{23}$ There are several categories of DSD, namely: 46,XY DSD (previously known as Male Pseudohermaphrodite), 46,XX DSD (previously known as Female Pseudo-hermaphrodite), Ovotesticular DSD (previously known as True Hermaphroditism) and XY sex reversal 46,XY complete Gonadal Dysgenesis, and Partial Gonadal Dysgenesis. Each category has their own symptoms and physical characteristics. ${ }^{24}$

\section{46,XY DSD (previously known as Male Pseudo-hermaphrodite)}

This disorder occurs in individuals who have male chromosomes, but their organs fail to grow into the normal male genitals. There are several types of male hormone disabilities that causes 46,XY DSD, the most common one is Androgen Resistance Syndrome or Androgen Insensitivity Syndrome (AIS) or Insensitivity TesticularFeminization Syndrome. AIS can occur in the form of Complete Androgen Insensitivity Syndrome (CAIS) or Incomplete/ Partial Androgen Insensitivity Syndrome (PAIS). In the Complete Androgen Insensitivity Syndrome (CAIS), the patient looks like a normal woman with the external genitalia of a woman as well, but have a vagina shorter than normal, and their breasts will grow at puberty with normal or slightly elevated testosterone hormone levels. Physical examination and ultrasound (USG) will show palpable or visible two generally undeveloped testes located in the abdomen or groin, without the structure of the female genitals. Therefore, girls who have inguinal hernia (a lump in the groin) before puberty and has never had their period since birth, need a chromosome examination. Patients with an incomplete form of androgen insensitivity demonstrate a spectrum of external genitalia ranging from very feminine to increasingly masculine and sometimes found in normal but infertile (cannot have a child) men. PAIS patients have small penises that look like an enlarged clitoris, accompanied by severe hypospadias (urethra does not pass through the penis), which divides the scrotum so that it looks like the vaginal opening, followed by other physical abnormalities. Often in adulthood the breasts grow and the Adam's apple appears even though the voice does not change. ${ }^{25}$

\section{46,XX DSD (previously known as Female Pseudo-hermaphrodite)}

Patients with 46,XX DSD have female chromosomes (46, XX), their ovaries and the internal Müllerian structures are consistently present. Ambiguous genitalia are limited to the appearance of the exterior due to androgen exposure in utero. Overall, $\mathrm{CAH}$ (Congenital adrenal hyperplasia) is the most frequent cause of these ambiguous genitalia in the newborns. $\mathrm{CAH}$ is classified into the classical type and non-classical type. The classical type arises in the womb and often dies in the first month after birth.

$\mathrm{CAH}$ presents a spectrum of abnormalities. There are patients with the appearance of a female but have masculinization syndrome. They show symptoms of an enlarged

\footnotetext{
${ }^{23}$ The phase of development of DSD in biological approach is beyond of this writing.

24 See Bambang Widhiatmoko and Eddy Suyanto, "Legalitas Jenis Kelamin", pp.16-18. See also Joel Hutcheson, et. al, "Disorder of Sex Development", http://emedicine.medscape.com/article/1015520-overview, accessed on 4 June 2016.

${ }^{25}$ Ibid.
} 
clitoris similar to the penis at or after birth. Often, people assume that those women's genitals change, so that the woman transitions into a man. Patients with male appearances are rarely reported because they have premature puberty without showing ambiguous genitals. CAH may result from several metabolical defects, one of which is 21 -hydroxylase deficiency. In $90 \%$ of patients with $\mathrm{CAH}$, the block is at the 21-hydroxylation enzyme. This leads to a mineralocorticoid deficiency and a build-up of androgenic byproducts, which causes masculinization of a female fetus. In children with $\mathrm{CAH}$, endocrine stabilization must be individualized, a process that usually takes several weeks. They can be treated to avoid more severe symptoms, treatment should be done as early as possible and lasts a lifetime. ${ }^{26}$

\section{Ovotesticular DSD (previously known as True Hermaphroditism)}

This diagnosis is made when a microscopic examination of tissue shows gonads consisting of both ovarian (female) and testicular (male) tissue. Gonadal findings may be any combination of ovary and testes, or so-called as the ovotestis. An ovotestis is most common and is found in approximately two thirds of patients. The most common $(70 \%)$ karyotype is $46, \mathrm{XX}$, and the rest are $46, \mathrm{XY}$ (male) or mosaicism mixture of $46, \mathrm{XX}$ (female) and 46,XY. Clinical manifestations and hormonal profiles depend on the amount of functioning gonadal tissues. Their ovarian tissues often function normally but most are infertile. In approximately $66.7 \%$ of the cases, patients grow up to become a man. Usually, the genitalia of the patients are ambiguous or predominantly female and is accompanied by the growth of breasts at puberty. Gonadal tissues can be found in the abdomen, groin, and in the scrotum area or at the genital fold. A testicle, when present, is more likely to exist on the right (57.4\%), and an ovary, when present, is more common on the left (62\%). Spermatozoa are rarely found. If the patient chooses to become a man, this is an indication for genital reconstruction and selective gonad cutting. If the patient chooses to become a woman, the surgery will be simpler. ${ }^{27}$

It is worth noting that in this case, the doctors usually let the patient or the parents of the patient choose the sexual identity. The doctors do not decide on their own.

\section{XY sex reversal 46,XY complete Gonadal Dysgenesis and Partial Gonadal Dysgenesis}

Gonad dysgenesis is characterized by the absence of oocytes and ovaries, or gonads appear like a line (streaky). Phenotypically, patients are women but can have various karyotypes, including XY (male). Patients with XY chromosomes do not produce testosterone. In most cases, patients have Turner Syndrome with 45,X0 karyotype. They have the characteristics associated with anomalies of short stature, webbing of the neck, high-arched palate, chest shields, cardiac anomaly, etc. The absent of oocytes in the case of 45,XO is due to the increasing loss of oocytes and not because of the germ cell abnormalities.

Partial gonadal dysgenesis can be classified as either 46,XY DSD or sex chromosome DSD if there is mosaicism (45,X/46,XY). In mixed gonadal dysgenesis (MGD), a streak gonad is usually present on one side and a testes (usually dysgenetic) on the opposite side. Although the degree of virilisation varies, all patients have a vagina and a uterus, and most have a fallopian tube, at least on the side of the streak.

\footnotetext{
${ }^{26}$ Ibid.
}

${ }^{27}$ Ibid. 
Most patients with MGD have a mosaic karyotype, 45,X/46,XY. A characteristic of patients with a 45,X karyotype is short stature. Patients who have no internal Müllerian remnants usually have no 45,X component. MGD is the second most common genital ambiguity after $\mathrm{CAH}{ }^{28}$

\section{47,XXY ( Klinefelter syndrome and variants)}

Klinefelter syndrome is a chromosomal condition that affects the male physical and cognitive development. Its signs and symptoms vary among affected individuals. Affected individuals typically have small testes that do not produce as much testosterone as usual. Testosterone is the hormone that directs male sexual development before birth and during puberty. A shortage of testosterone can lead to delayed or incomplete puberty, breast enlargement (gynecomastia), reduced facial and body hair, and an inability to have biological children (infertility). Some affected individuals also have genital differences including undescended testes (cryptorchidism), the opening of the urethra on the underside of the penis (hypospadias), or an unusually small penis (micropenis). ${ }^{29}$

\section{B. Treatment and handling of Patients with DSD}

People with DSD can have hormonal therapy and even surgery for reconstruction. If the patient is a male, the purpose of therapy is to support the masculinity and supress the femininity by giving testosterone. If the patient is a female, the same principle of handling is required. Hormone therapy usually starts when the patient is entering teenagehood. The hormonal therapy must be given for the rest of his or her life to maintain their sexual characteristics. Any reconstruction surgery can be performed gradually. Ambiguous genitalia needs a holistic handling to cover not only medical aspect, but also the psychology, social and legal aspects. ${ }^{30}$

According to the consensus of paediatricians, the treatment or handling of ambiguous genital patients could be optimal if the gender of the respective baby is not determined yet. An evaluation conducted by a competent expert who has experience is required. The baby needs several examinations before he or she is classified as a boy or a girl for civil registry purposes. The diagnosis needs to be accepted in good manner by all parties, in particular the baby's parents. The communication between the patient and their family as well as their participation in the decision making process are important.

Early evaluation or examination can be conducted by a child endocrine expert, but the medical handling needs more care. Treatments and the handling must be performed gradually. In some cases, surgery needs to be done before the patient is 2 years old. Handling by psychologists or psychiatrists is a must for patients beyond 2 years old. A team consisting of paediatric subspecialists in endocrinology, surgery or urology or both, psychologist or psychiatrist, gynaecology, genetics, neonatology, if possible social worker and medical ethics expert is needed. The formation of the team depends on the type of disorder, local resources, development context, and location.

${ }^{28}$ Ibid.

29 Genetics Home Reference, "Klinefelter Syndrome”, https://ghr.nlm.nih.gov/condition/klinefeltersyndrome, last accessed 24 August 2016.

${ }^{30}$ Bambang Widhiatmoko and Eddy Suyanto, “Legalitas Jenis Kelamin”, pp.17-18. 


\section{A person with DSD is not the same as Transsexual}

People with DSD are not equal to transsexuals. Transsexuality is a psychological disorder. The genital organs of the person could be identified easily. However, the soul inside him or her feels trapped inside the wrong body as if it has the opposite gender. ${ }^{31}$ Then, she or he acts according to his or her feelings. Sometimes the feeling is consequently passionate until the person enters into a decision to have a sexual transgender surgery.

An official statement from the Central Management of the Indonesian Psychiatric Association (Pengurus Pusat Perhimpunan Dokter Spesialis Kedokteran Jiwa IndonesiaPP PDSKJI) issued on February $19^{\text {th }}, 2016$, stated that homosexuals and bisexuals are categorized as "people with psychiatric problem" or ODMK (Orang dengan Masalah Kejiwaan) and a transsexual person is categorized as a "mentally ill person" or ODGJ (Orang dengan Gangguan Jiwa). ${ }^{32}$

Based on the cases and description mentioned above, the sexual identity bias could be divided into two parts: people with DSD and transsexualism.

\section{LEGAL ASPECTS OF SURGERY TO PERSON WITH DSD}

\section{A. Legal Basis of Reconstruction Surgery in Indonesia}

\section{The Indonesian Health Law}

The health stipulations in Indonesia are embodied in the Indonesian Health Law.33 It states that plastic surgeries and reconstructions can only be performed by medical workers who have the skill and authority to do so. Such plastic surgeries and reconstructions cannot contradict with the prevailing norms in the society and cannot be performed to change the identity. ${ }^{34}$

Any person who, on purpose or intentionally, performs any plastic surgery and reconstruction in order to change the identity of a person shall be sentenced to jail at a maximum of 10 years and fined a maximum amount of IDR 1,000,000,000.35

Due to none of any further stipulation in government regulations as the lower rank of the Indonesian Health Law and pursuant to the transitional provision of the Indonesian Health Law, the previous regulations remain to be effective as long as it is not in contradiction with stipulations in the Indonesian Health Law. ${ }^{36}$ Therefore, the Decision Letter of the Minister of Indonesia No.292/MENKES/SK/III/1989 dated June $12^{\text {th }}, 1989$, regarding plastic surgery and reconstruction remains valid.

\footnotetext{
${ }^{31}$ Ibid.

32 Indonesian Psychiatric Association (Pengurus Pusat Perhimpunan Dokter Spesialis Kedokteran Jiwa Indonesia-PP PDSKJI), "Pernyataan Sikap PengurusPusatPerhimpunanDokterSpesialisKedokteranJiwa Indonesia [Statement of the Central Board of the Association of Indonesian Psychiatric Specialist]" dated 19 February 2016, http://pdskji.org/img galeri/33648SuratPernyantaanPDSKJI.jpg accessed on 4 June 2016.

${ }^{33}$ Indonesian Health Law

${ }^{34}$ Ibid., Art.69.

${ }^{35}$ Ibid.,Art.193.

${ }^{36}$ Ibid.,Art. 203.
} 


\section{i. Decision Letter of the Minister of Indonesia No.292/MENKES/SK/III/1989 dated 12 June 1989}

The Decision Letter of the Minister of Indonesia No.292/MENKES/SK/III/1989 dated June $12^{\text {th }}, 1989$, regarding plastic surgery and reconstruction also covers the genital reconstruction surgery. This decision letter was issued to protect patients with depression or mental illness to allow reconstruction genital organs through plastic surgery to clarify their sexual identity. ${ }^{37}$ This regulation has the purpose to assist if the reconstruction surgery becomes the only way to help them confirm and determine their sexual identification. ${ }^{38}$

Such decision letter appointed that only hospitals and an expert teams can perform any reconstruction surgery. The expert team must consist of, among others: urologist, anesthesiologist, psychiatrist, psychologist, internist, biologist, obstetrician and gynaecologist, legal expert, and officer of the Department of Health.

This decision shows that plastic surgery and reconstruction surgery to clarify the identity sexual is still allowed in Indonesia. In addition, for people with DSD, this surgery is essential and necessary. Beyond of those purposes, according to Indonesian Health Law, it is forbidden. The author humbly suggests that this decree is renewed to confirm the permission.

\section{Human Rights Law}

The Indonesian Human Rights Law ${ }^{39}$ mentions the district courts decisions as the legal basis of the reconstruction surgery. This law serves as a legal basis for it stipulates that everyone has the right and is entitled to legal recognition, guarantee, protection, and equal treatment as well as to obtaining legal certainty before the law. ${ }^{40}$

The Indonesian Human Rights Law states that everyone has the right and is entitled to their personal integrity, spiritually or physically. Therefore, no research could be performed without any consent from him/her. ${ }^{41}$ The phrase "personal integrity (keutuhan pribadi)" became the stressing point from the judge, that the sexual identity of a person must be the same with the data in their legal documentation. It also stipulates that everyone has the right and is entitled for recognition before the law as a human being anywhere. ${ }^{42}$ Those articles give rights to everyone, including individual who undergone sexual reassignment, to be equally treated before the law and have the right to have personal integrity as well as the identity.

The above comes from Article 28I of Indonesian Constitution which states that recognition as a person as part of his/her human rights, and that people with DSD are also Indonesian civillians who are entitled of such rights. ${ }^{43}$

37 Tim Analisis dan Evaluasi tentang Pengaturan Bedah Plastik, Analisa dan Evaluasi Hukum tentang Pengaturan Bedah Plastik [Legal Analysis and Evaluation regarding Plastic Surgery Practice Regulations], (Jakarta: Badan Pembinaan Hukum Nasional, 1996), p.14.

${ }^{38}$ Ibid.

39 Indonesia, Undang-Undang tentang Hak Asasi Manusia (Law regarding Human Rights), UU No. 39 tahun 1999, LN No. 165 tahun 1999 (Law No. 39 of 1999, SG No. 165 of 1999).

${ }^{40}$ Ibid., Art.3(2).

${ }^{41}$ Ibid.,Art.21.

42 Ibid.,Art.29 (2).

43 Indonesia, Undang-undang Dasar 1945 (Indonesian Constitution 1945), Art. 28I (1). 


\section{Civil Administration Law}

The Indonesian Civil Administration $\mathrm{Law}^{44}$ is the legal basis for revision of the sexual identity in the Civil Registration Office. After the reconstruction surgery, if necessary, the data in the legal documentation should be adjusted. This is important to determine the rights and obligations of the person. In Islam, this issue takes a lot of attention since the portion of inheritance is depending on the gender of the heirs.

Based on the Indonesian Civil Administration Law, any data or details in legal documents, among others, birth certificate or marriage certificates, can only be amended upon a decision of a district court. Therefore, any amendment to the data of sexual identity must obtain a prior decision of district court, ${ }^{45}$ whereby the change of the sexual identity is included as "Other Important Event" (Peristiwa Penting lainnya). ${ }^{46}$

\section{B. The Decisions of District Courts}

The author randomly collected 14 decisions of district courts within Indonesia regarding the change of sexual identities. ${ }^{47}$ These cases will be analyzed to see the legal reasoning of the district court decisions and to see which party has the authority to determine the sexual identity of a person.

\section{Reassignment Surgery and Reconstruction Surgery}

Those decisions could be divided into two types; first, the decision after the reconstruction surgery, and second, the decision after the reassignment surgery. Both of them followed with revisions of the data in the Civil Registration Office.

In the first type, the judges mentioned their considerations about the physical conditions as well as the psychiatric conditions. The judges mentioned that the surgery was seconstruction surgery instead of transsexualism. The judges valued the testimony of the doctors who were involved in the surgeries and valued them as professionals who were working under the oath and subject to the ethics of the Indonesian Medical Association (IkatanDokter Indonesia).

These surgeries were mentioned as the reconstruction surgery, whereby the purpose is to reconstruct the genital organs according to the dominant physical condition of the patients. The judges considered that prior to the surgery, the doctors must perform long and variety assessments to their patient. It stated that there are 5 aspects that determine the sexual identity of a person, which are: the chromosome (XX or XY), hormone (testosterone or estrogene and progesterone), primary genital organs (testes or ovary), external organ genital (penis or vagina) and genes.

Two decisions of the first type of decisions mentioned that the patients has two primary genitals though both of them were imperfect. Prior to the surgeries, the

44 Indonesia, Undang-Undang tentang Administrasi Kependudukan (Law regarding Civil Administration), UU No. 23 tahun 2006, LN No. 124 tahun 2006 (Law No. 23 of 2006, SG No. 124 of 2006). (hereinafter referred as "Civil Adminisration Law")

45 Indonesia, Undang-Undang tentang Kekuasaan Kehakiman (Law regarding Judicial Authority), UU No.48 Tahun 2009, LN No.157 Year 2009 (Law No.48 of 2009, SG No.157 of 2009), Art.50. (hereinafter referred as Judicial Authority Law).

${ }^{46}$ Civil Administration Law, Art.56 (1). The Important Event is including the change of sexual identity.

47 The decisions of district courts are detailed in footnote No.14 above. 
doctor authorized the patients to choose and give statement as to what he or she would like to be in the future. Interestingly, one of the patients was grown as a girl within his family, however he felt more comfortable as a man. The psychiatrist performed a personal status examination upon him and advised to follow his statement. The psychiatrist mentioned if he becomes a woman due to the will of his parents, he could suffer depression for the rest of his live.

Two decisions are in the second type, namely the reassignment surgery. In the first case, the judge does not mentioned the condition and testimony of patient. It appeared that the respective patient had no birth certificate. The parents of the patient followed the statement of the patient. The situation of no birth certificate and the attitude of the parents indicated that there was a situation in which they did not want to disclose. The other case mentioned that even though the chromosome, primary genital organ, and external organ show that the patient is a man, the hormone is unbalanced. The psychiatric examination mentioned that she was in a good state to express herself and fulfil the requirement to have the surgery.

These decisions showed that in determining the sexual identity, the biological conditions and psychiatric condition are taken into account. The physical condition of the patients were examined first, and then the result will be matched with the statement of patients through the psychiatric examination. In true hermaphrodite cases, the choice of respective patients that are confirmed by a psychiatric test, is a component that determines the sexual gender of the patient.

The decisions in both types mention that the facts after the surgery does line up with the data in the Civil Registration Office or legal documents. Therefore, the judges gave permission and granted the request of the applicants and or the patients (some applicants were the parents of the patients, some applicants were the patients themselves) to request revisions in the Civil Registration Office.

\section{The Statements from the judges}

From the entire decisions, there are interesting legal considerations from the judges. Majority of the judges mentioned that there are no prevailing laws or regulations regarding the transsexual. However, the judges cannot refuse the case for such reason since the judge must adjudicate the case and find the legal norms. ${ }^{48}$ Some cases which were issued before the Indonesian Health Law mentioned that they adjudicate the case pursuant to the general principal of law. Majority of the judges considered the psychical condition of the applicants or patients pursuant to the expert witnesses. The judges then considered that the reconstruction surgeries that were succeeded that made the factual condition did not line up with the legal data anymore. Then, the judges granted the request to revise the data according to the Civil Law Administration.

In some decisions, the judges considered the fact that the sexual identity is indeed important to Muslims since their sexual identity determine the portion of inheritance. Some decision also mentioned the considerations of conformity or happiness of the applicants or patients as human beings.

One of the judges mentioned that the reassignment surgery and reconstruction surgery does not depend only on the financial capacity to compensate all the expenses. Prior to these surgeries, the patients must fulfill particular standards and all required

\footnotetext{
48 See Judicial Authority Law, Art.10.
} 
examinations, physically and mentally. Therefore, there is no reason to worry that a lot of individuals will have such surgery. In addition, the doctors or medical workers have their particular standards according to the Indonesian Doctors Association (IDI) and, most of all, they are working under the sacred oath.

The same judge who mentioned the above consideration also mentioned that part of the Indonesian society believes that transsexuality is against fate. However, differences in opinions are something common and reasonable as Indonesia has a heterogenic society that makes values vary. The different opinions within the society cannot be the background for the State to not recognize the rights of its citizens which is guaranteed by the Indonesian Constitution. The State must give a lesson to its society in order to make them appreciate the differences of opinions and values within them. The State must provide justice to each of its citizens, even with the variety of opinions.

Some judges looked into some opinions from religious organizations or religious norms. The author agrees to this respect, however, the judge must also consider the religious norms according to the religion of the applicant or patient. One of the decisions mentioned the norms of Islam, while the applicant should be considered as a Buddhist. ${ }^{49}$ The author supports if the judge calls upon religious experts from the same religion of the applicant or patients, in this case, an expert from Walubi, the Indonesian Buddhist Association.

The judges granted the request of applicants whether the applicants became a man or a woman, and therefore he or she will bear the rights, titles, and obligations according to their new sexual identity. Unfortunately, not every judge mentioned the effectiveness of their decision. Therefore, pursuant to the general principles, it will be effective as of the issuance date of the respective decisions.

In relation to the question as to whether or not a person may change their sexual identity, no regulation has mentioned about it. The Indonesian Health Law states that plastic surgeries which causes changes in the sexual identity is forbidden. However, having considered and looked through the relevant decisions as well as physical and health condition, the author humbly advises to see the determination of "change of sexual identity", separated with the condition of a person with DSD that need the reconstruction surgery.

According to court decisions, experts (the doctors and their team) have clarified the biological condition of the patients. In some cases when the condition is vague, the statement of the patient or the parents is/are requested. It shows that the sexual identity depends on what nature has given the person. If the judge would like to take the liberty to determine the sexual identity of a person, it is advisable that the judge should be assisted by medical experts and psychiatrists, as well as other experts. When expert doctors have different opinions, it will be wise if the judge could take a third opinion.

\section{B. The Capacity to Marry as one of Legal Consequences}

The district court decisions, after having granted the request, mentioned that the data in the legal documentation shall be amended and, furthermore, the person shall be identified as having the gender as mentioned in the respective decision, along

${ }^{49}$ Ungaran District Court, "Decision No.518/Pdt.P/2013/PN.Ung." The parents of applicant were married in Vihara as they are Buddhist. The applicant did not mentioned his religion, so his religion could be considered the same as his parents, as mostly happened in Indonesia. 
with any legal consequences that has arisen from the new gender. Therefore, the legal position including his/her rights or obligations will correspond with the sexual identity as stated in the latest legal documents which is revised based on the district court decision.

In relation with the ability to marry, as the requirement of marriage is a heterosexual couple, the person can only marry the opposite sex of his/her current sexual identity. If the decision of the district court mentions that now the claimant is a man, he can only marry a woman, and vice versa.

In relation to this, the Civil Registration Office and the Religious Affairs Office have the authority to examine the requirements of the groom, bride, and the wali nikah to marry. ${ }^{50}$ If the officer finds an objection, the officer may refuse to hold the marriage.

In relation with the people who have undergone reassignment surgery or reconstruction surgery, can the Civil Registration Office and the Religious Affairs Office refuse and set aside the district court decision? The author humbly advises that the Civil Registration Office and the Religious Affairs Office use the authority to examine the capability or the substance requirements of the couple based on the legal documents. It should not set aside the legal documents, for instance, the district court decision as the legal evidence with regards to the sexual identity. Therefore, for avoidance of doubt, it is advisable if the MA 1974 is amended to regulate the definition of a man and a woman in the definition of marriage, and that it shall be proven according to the latest identity card issued according to the Indonesian Civil Administration or any district court decision, as it is relevant and necessary.

\section{PERSON WITH DSD: QUO VADIS?}

\section{A. Bissu in Bugis' Culture, one of the Indonesian Ancestor's Culture}

Life is not always "normal" in some cases. In particular cases, people are born with a variety or multiple genders and they are (still) recognized as "normal" or even "sacred" within their local society. For instance, in Bugis, Indonesia, there are "Calalai", "Calabai" and "Bissu" which stands in between a "normal" man and a "normal" woman.

Calabai are male-bodied people who dress like women, perform women roles, and often have male partners. They are visible in society and perform various functions in marriage ceremonies. Calalai are much rarer and much less visible. They are femalebodied people who may live with their women partners and fulfill male roles. They do not perform any role in marriage ceremonies or ritual ceremonies. Some of Calabai could be a Bissu through "supernatural" call, but Bissu must be regarded on its own.

Another gender is known as Bissu. A Bissu has two outer genitals in their bodies. One could be dominant from the other. They cannot be called as a man or a woman, they are called as Bissu. Their existence is considered as the union of man and gods, as they believed of the origin of Bugis tribal, known as "I La Galigo". They are becoming the medium between their god and human beings; therefore their role is important in the society. They are the guardian of the ancestor's heritage and play the important role in traditional ritual ceremonies. ${ }^{51}$

50 Indonesia, Peraturan Menteri Agama tentang Pencatatan Nikah (Regulation of Minister of Religion regarding Marriage Registration), Peraturan Menteri Agama No.11 Tahun 2007, LN No.5 Year 2007 (Regulation of Religion Minister No.11 of 2007, SG No.5 of 2007), Art 9 (1) jo. Art.12 (1) jo. Art. 15.

${ }^{51}$ Saskia E. Wieringa, "Gender Variance in Asia, Discursive Contestations and Legal Implications," Gen- 
Bissu has an important ritual function. They used to be the keepers of the sacred royal ornaments and in condiucting that function, they were seen to be bisexual, as these ornaments required communion with the other sex. A Bissu adorns the left side of hir hair with (considered as a female habit) and carries a keris (ritual dagger) on the right side. ${ }^{52}$ The ambiguous sexual identity of Bissu was and is still highly appreciated.

Graham quotes a clearly intersex Bissu, named Haji Yamin, who said that in order to become a Bissu, an individual must be born for such purpose. Such individual cannot have a "normal" penis which is able to be erect and ejaculate as an external genital, if he does then he cannot become a Bissu. ${ }^{53}$

Sacred gender is associated with a worldview in which gender is defined cosmologically in such a way that there is a direct link between sacred powers and a (third) sex/gender. Sacred gender widely refers to cosmologies that "constitute gender" meanings and practices through sacred belief about the nature of the cosmos and the origins of humanity. ${ }^{54}$ Original myths frequently stress an original unity (a snake or an egg) from which diversity originates. The Bugis myth about creation, I La Galigo, speaks of originally "androgynous" deity that produces various sacred beings, including Bissu. In a later form of creation, the primordial unity splits, woman and man are created. These became the ancestors of the Bugis dynasties, thus Bugis cosmology rests upon a primordial oneness, of which Bissu are a manifestation. Later they are split into opposite genders. The Bissu remains necessary to ensure the original oneness, through their participation in regular rituals. ${ }^{55}$

Bissu in the Bugis tribe is a classic phenomenon which is nowadays known as a person or patient with DSD. These days, those people could be advised to have treatment to determine their sexual identity. Hormone therapy up to reconstruction surgery could be performed to assist them to be a man or a woman, according to the diagnosis of the doctor(s).

\section{B. Person with DSD in other part of Indonesia's Culture}

Adhanarish (also called as Ardhanari) is a half-male and half-female deity that combines male (right side, Siva) and female (left side, Shakti) characteristics and attributes. Originally from India, this God or Goddess is known in Indonesia as well. The National Museum in Jakarta has three statues of Ardhanarishvari in its central yard. In pre-Islamic Javanese's epic court poetry called kakawin, Ardhanarishvari is mentioned as a tantric from of the yoga of love in which the divine union of Siva and Shakti creates the "seed of the world" (windu). This cosmic union provides both sexual gratification and the welfare of the land; it ensures an abundance of life in general. This fusion of male and female in one form refers to both spiritual prowess and the physical enjoyment of love. ${ }^{56}$

The same phenomenon could be seen in Basir or Balian in Ngayu Dayak, Kalimantan. That Balian are men with women's costume who are powerful healers and diviners. There are also dancers of janthilan in Warok Ponorogo. They are men who dance femininely. However, the author did not have any report which confirms

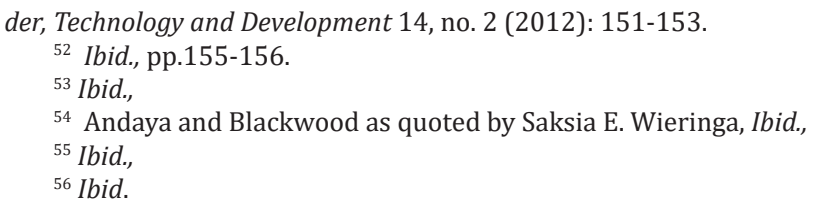


whether or not they are people with DSD. Therefore, the author could not conclude firmly whether they are similar to Bissu as described above.

The above traditions in Indonesia demostrates that people with DSD such as Bissu (and other genders) were acknowledged and could live as it is. Bissu are considered normal, if not sacred people. They neither are advised nor pushed to have one gender, and they have equal rights along with the others. A Bissu has a sacred position in society. It is shown, even before Indonesia has the Indonesian Human Rights Law, it is already value and respects the human rights, even with the unique gender.

\section{Religions' Values on People with DSD}

The values discussed in this sub-chapter should cover the religions that exist in Indonesia, namely Islam, Christian, Catholic, Hindu, Buddha and Confucius. ${ }^{57}$ Indonesia respects and acknowledges other religions, but considering the number of the believers, only six religions as mentioned above which will be discussed in this writing.

\section{Islam}

In relation with Islam's values, the author would like to refer to two opinions of Islamic organizations that exist in Indonesia, namely the Indonesian Ulama Council (Majelis Ulama Indonesia, the "MUI") and Nahdatul Ulama (the "'NU"). Both of these organizations, issue Fatwas ${ }^{58}$. In relation to sexual reassignment, the MUI issued a fatwa in $2010 .{ }^{59}$ MUI views that transsexual surgery to change the genital or sexual

\footnotetext{
${ }^{57}$ Indonesia, Undang-undang tentang Pencegahan Penodaan Agama, UU No.1/PNPS/1965 (Law No.1/ PNPS/1965).

Indonesia, Undang-Undang tentang Pencegahan Penodaan Agama (Law regarding the Prevention of Blasphemy), UU No. 1/PNPS/1965 (Law No. 1/PNPS/1965). The official elucidation of Art.1 par. 1 and 2 "... Agama-agama yang dipeluk oleh penduduk di Indonesia ialah Islam, Kristen, Katolik, Hindu, Budhadan Kong Hu Chu (Confusius). Hal ini dapat dibuktikan dalam sejarah perkembangan agama-agama di Indonesia. Karena enam macam agama ini adalah agama-agama yang dipeluk hampir seluruh penduduk Indonesia, maka kecuali mereka mendapat jaminan seperti yang diberikan oleh Pasal 29 ayat (2) UUD, juga mereka mendapat bantuan-bantuan dan perlindungan seperti yang diberikan oleh Pasal ini" freely translated as "... religions embraced by the Indonesian people are Islam, Christianity, Catholicism, Hiduism, Buddhism, Confucianism. It can be proven in the history of religions in Indonesia. Because six religions are the religions that embraced by almost entire populations of Indonesia, then, unless they get a guarantee as provided by Article 29 paragraph (2) of the Constitution, they also received assistance and protection as provided in this Article." However, such stipulation does not forbid the existence of any other religion in Indonesia. The other religions have protection according to Art.29 (2), provided it is not in contradiction with the prevailing rules and regulations. See the official elucidation art.1 paragraph 3.

58 M. Erfan Riadi, Kedudukan Fatwa ditinjau dari Hukum Islam dan Hukum Positif (Analitis Yuridis Normatif) [Position of Fatwa, from the Perspective of Islam Law and Positive Law (Normative Juridical Analysis)], Ulumiddin 4, no. 6 (January-June 2010). Fatwa in Indonesian Dictionary defines as advices or opinion from Islamic scholar. It is an Islamic religious ruling, scholarly opinion on a particular mater based on Islamic Law. The analogy might be made to the issues of legal opinion from courts in common-law systems. Fatwa is issued by a recognized religious authority in Islam. However, as there is no hierarchy of priesthood in Islam, a fatwa is not necessary binding to all Moslem. The people who pronounce fatwa supposed to be knowledgeable and wise persons. They must provide the evidence from Islamic sources of their opinions. It is un-common that the scholars come into different opinion at the same particular issue. Some Muslims look at the opinion, sometimes the person who gives the opinion, the evidence given to support it, and then decide whether they want to follow it or not. (Taken from variety sources, among other Indonesian Big Dictionary (KamusBesarBahasa Indonesia).

59 Indonesia Ulema Council (Majelis Ulama Indonesia), the 2nd National Conference (Musyawarah-
} 
organs of a person is prohibited. It is also forbidden to assist a person to do such thing. However, the MUI allows the perfection of sexual organs of intersex people, either female-to male reassignment or vice versa, as long as it tends to the dominant function. According to this fatwa, the position of a person shall be the same as the condition of the person before the transsexual surgery, even though a district decision is already issued to determine the latest condition of the respective person. NU has the similar views and has stated that operation or reassignment to perfect the genital to be in line with the internal organs of a person is allowed. ${ }^{60}$

\section{Christianity}

The church of Christianity in Indonesia has no objection if such reassignment surgery is the only way to assist the patient in order to live as a normal person. ${ }^{61}$ However, there is no renewal of opinions regarding intersexual people from the church's associations. If any, according to the author they are related to LGBT issues than people with DSD issues.

The author did not find any opinion from Catholicism in Indonesia, Persada Hindu Dharma - the Indonesian Hindu Congregation, or Walubi - the Indonesian Buddha Association, Matakin - Indonesian Confucius Congregation. The author herein would like to encourage their scholars to give opinions in order to provide any references to the judges or anyone else, as it is relevant and necessary.

In relation to the above, the author would like to suggest that regulations could give a chance to people with DSD to choose what they want to be. As the judges have mentioned, there is no regulation as to whether a person could choose his or her sexual identity. The sexual identity is given from the nature. People with DSD are the exception, in particular the true hermaphrodite patients; therefore, they may choose. It is advisable that the conditions of people with DSD to be embodied in the prevailing laws and regulations, for avoidance of doubt. The fact that Bissu could live in their condition and be respected in society, could be one of the options. If the medical technology could help them to be completely a man or a woman, it is wise that the laws and regulations could (also) give this option. Thus, their rights and obligations that correspond to their sexual identity, including the right to marry their opposite sex could have legal certainty.

\section{CONCLUSION}

A. People with DSD or Intersexual people exist in Indonesia. They are the individuals who cannot be simply categorized as a man or a woman. In Bugis culture, they are called as Bissu.

B. According to the Indonesian Health Law, the reassignment surgery is forbidden; however, the reconstruction surgery is allowed as it has the purpose to confirm the sexual identity of people with DSD.

\footnotetext{
Nasional) on 1980 which re-confirmed in the 8th National Conference on 27 July 2010, Fatwa MUI No.3/ MUNAS-VIII/MUI/2010 regarding Sexual Reassignment and Perfection of Genitals.

${ }^{60}$ Ungaran District Court, "Decision No.518/Pdt.P/2013/PN.Ung.", p.13. It quoted the Decision of the 26th Conference (Muktamar) of NU in Semarang on 11 June 1979.

${ }^{61}$ South and West Jakarta District Court, "Decision No.546/Pdt.P/1973," p.4. It quoted the testimony of Pastor Eka Dharma Putra to represent the Christianity values.
} 
C. To determine a sexual identity, Indonesia relies on the physical and psychiatric condition of a person. Only when a person is a patient of true hermaphrodite can the person or their parents choose one their sexual identity.

D. The district court decisions were issued only to revise the civil registration office data and/or any legal documentation, instead of granting approval or determining the gender of a person.

E. The men and women as mentioned in the definition of marriage in the MA 1974 should include the men and women who have undergone the reconstruction surgery to confirm their identity, as mentioned in the respective district court decisions. However, this condition has yet to be reflected in the MA 1974.

F. The man and the woman with the revision as mentioned in their respective district court decisions can only marry their current opposite sex. They also bear the rights and obligations as their latest sexual identity.

G. It is advisable for Indonesia to firmly give the definition of "man" or "woman" in the requirements of marriage for avoidance of any doubt.

H. It is advisable that Indonesia issues a regulation to respect people with DSD regarding the freedom to choose one sexual identity which the reconstruction surgery will be due; or stay in their given nature. Their choice and existence should be respected as it has happened centuries ago in Indonesia. 


\section{Bibliography}

\section{Legal Documents}

Law and Regulations

Burgerlijk Wetboek. 30 April 1847, Staatblad. 1847-23 (Indonesian Civil Code)

Indonesia. Undang-undangDasar 1945 (Indonesian Constitution 1945)

---. Undang-Undang tentang Pencegahan Penodaan Agama (Law regarding Prevention of Religious Demafation), UU No.1/PNPS/1965 (Law No.1/PNPS/1965).

---. Undang-undang tentang Perkawinan (Law regarding Marriage), UU No.1 tahun 1974, LN No.1 tahun 1974, (Law No.1 of 1974, SG No.1 of 1974).

---. Peraturan Pemerintah tentang Pelaksanaan UU No.1 tahun 1974 tentang Perkawinan (Government Regulation regarding the Implementation Regulation of Law No.1 of 1974 regarding Marriage). PP No. 9 tahun 1975, LN No. 12 tahun 1975, TLN No. 3050 (Government Regulation No.9 of 1975, State Gazette No.12 of 1975, Supplement No. 3050).

---. Undang-undang tentang Hak Asasi Manusia (Law regarding Human Rights). UU No.39 tahun 1999, LN No.165 Tahun 1999 (Law No.39 1999, SG No.165 Year 1999.

---. Undang-undang tentang Administrasi Kependudukan (Law regarding Civil Administration). UU No.23 tahun 2006, LN No.124 Tahun 2006 (Law No.23 of 2006, SG No.124 Year 2006).

---. Undang-undang tentang Kesehatan (Law Regarding Health). UU No.36 tahun 2009, LN No.144 Tahun 2009 (Law No.36 of 2009, SG No.144 Year 2009).

---. Hukum tentang Kekuasaan Kehakiman (Law regarding Judicial Authority). UU No.48 tahun 2009, LN No.157 tahun 2009 (Law No.48 of 2009, SG No.157 Year 2009).

---, Minister of Religious Affairs. Peraturan Menteri Agama tentang Pencatatan Nikah (Minister of Religious Affairs Regulation regarding Marriage Registration). PMA No.11 Tahun 2007, LN No. 5 Tahun 2007 (PMA No.11 of 2007, SG No.5 of 2007).

---. Peraturan Pemerintah tentang Untuk Menikahdan Cerai Bagi Pegawai Negeri Sipil (Government Regulation regarding Permission to Marry and Divorce of Civil Servants). Peraturan Pemerintah No.10 tahun 1983 (Government Regulation No.10 of 1983, SG No. 13 Year 1983) as amended by Peraturan Pemerintah tentang Untuk Menikah dan Cerai Bagi Pegawai Negeri Sipil (Government Regulation regarding Permission to Marry and Divorce of Civil Servants), PeraturanPemerintah No.45 tahun 1990 (Government Regulation No.45 of 1990, SG No.61 Year 1990).

---. Peraturan Pemerintang tentang Disiplin Pegawai Negeri Sipil (Government Regulation regarding Disciplinary of Civil Servants). PP No.53 Tahun 2010 LN No.74 tahun 2010 (Government Regulation No.53 of 2010, SG No.74 Year 2010).

---, Ministry of Religious Affairs. Peraturan Menteri Agama tentang Pencatatan Nikah (Minister of Religious Affairs Regulation regarding Marriage Registration), PMA No.11 tahun 2007 (Regulation of Minister of Religion No.11 
of 2007).

Singapore, Women's Charter, the Singapore Marriage Law

Special Administrative Region of Hong Kong, Marriage Clause Ordinance.

---, Offence Against the Person Ordinance (Cap.212).

---, Marriage Reform Ordinance.

The District Courts Decisions

South-West Jakarta District Court. "Decision No.546/Pdt.P/1973.”

Semarang District Court, "Decision No.595/Pdt.P/1990/PN.Semarang."

Bantul District Court, "Decision No.22/Pdt.P/2003/PN.Btl."

Batang District Court, “Decision No.19/Pdt.P/2009/PN.Btg.”

Ungaran District Court, "Decision of No.20/Pdt.P/2009/PN.Ung."

Jayapura District Court, "Decision No.12/Pdt.P/2010/PN.Jpr."

Semarang District Court, "Decision No.3077/Pdt.P/2011/PN Semarang."

Boyolali District Court, "Decision No.07/Pdt.P/2011/PN.Bi."

Cibinong District Court, “Decision No.685/Pdt.P/2012/PN.Cbn."

Kendal District Court, "Decision No.3332/Pdt.P/2012/PN.Kdl."

Yogyakarta District Court, "Decision No.517/Pdt.P/2012/PN.YK."

Ungaran District Court, "Decision No.518/Pdt.P/2013/PN.Ung."

Boyolali District Court, "Decision No.54/Pdt.P/2015/PN.Byl."

Kebumen District Court, "Decision No.17/Pdt.P/2015/PN.Kbm.”

\section{Books}

Polk, H. Daniel. Abnormalities of Sexual Differentiation, Harrison's Endocrinology. New York: McGraw-Hill, 2006. pp. 161-172.

Polk, H. Daniel. Abnormalities of Sexual Differentiation, Harrison's Endocrinology. New York: McGraw-Hill, 2006.

Kum, Leong Wai. Elements of Family Law in Singapore. 2nd ed. Singapore: LexisNexis, 2013.

Tim Analisis dan Evaluasi tentang Pengaturan Bedah Plastik. Analisa dan Evaluasi Hukum tentang Pengaturan Bedah Plastik [Legal Analysis and Evaluation on Plastic Surgery Practice Regulation]. Jakarta: Badan Pembinaan Hukum Nasional, 1996.

Prodjodikoro, Wirjono. Hukum Perkawinan di Indonesia [Marriage Law in Indonesia]. Bandung: Sumur Bandung, 1991.

\section{Articles}

Riadi, M. Erfan. "Kedudukan Fatwa ditinjaudari Hukum Islam dan Hukum Positif 
(Analitis Yuridis Normatif) [Position of Fatwa, from the Perspective of Islam Law and Positive Law (Normative Juridical Analysis)]." Ulumiddin 4, no. 6 (January-June 2010): 468-477.

Ubbe, Ahmad. "Putusan Hakim sebagai "Rekayasa Sosial” dalam Pembinaan Hukum Nasional [The Decision Courts as "Social Engineering" in National Law Development]," Majalah Hukum Nasional, no. 1 (2002): 71-89.

Widodo, Joko Sri. "Putusan Hakim sebagai "Rekayasa Sosial" dalam Pembinaan Hukum Nasional [The Decision Courts as "Social Engineering" in National Law Development]." Majalah Hukum Nasional, no. 1 (2002): 62-73.

Widhiatmoko, Bambang and Eddy Suyanto. "Legalitas Jenis Kelamin pada Penderita Ambiguous Genetalia di Indonesia [Legal Aspect of Sexual Identity of the Ambiguous Genitals Patients in Indonesia]." Jurnal Kedokteran Forensik Indonesia 15, no. 1 (Jan-March 2013): 15-18.

\section{Other Sources}

Indonesia Ulema Council (Majelis Ulama Indonesia), the 2nd National Conference (MusyawarahNasional) on 1980 which re-confirmed in the 8th National Conference on 27 July 2010, Fatwa MUI No.3/MUNAS-VIII/MUI/2010 regarding Sexual Reassignment and Perfection of Genitals. 
